\title{
Comparative evaluation of nasal and alveolar changes in complete unilateral cleft lip and palate patients using intraoral and extraoral nasoalveolar molding techniques: randomized controlled trial
}

\author{
Ritesh Kalaskar, Priyanka Bhaje, Priyanka Sharma, Shruti Balasubramanian, Nupur Ninawe, Rajesh ljalkar \\ Department of Pediatric and Preventive Dentistry, Government Dental College \& Hospital, Nagpur, India
}

\begin{abstract}
J Korean Assoc Oral Maxillofac Surg 2021;47:257-268)
Objectives: Cleft lip and palate is a common congenital anomaly that impairs the aesthetics, speech, hearing, and psychological and social life of an individual. To achieve good aesthetic outcomes, presurgical nasoalveolar molding (NAM) has become important. Currently, the intraoral NAM technique is widely practiced. Numerous modifications have been made to intraoral NAM techniques, but the original problem of compliance leading to discontinuation of treatment remains unsolved. Therefore, the present study compared an extraoral NAM technique with the intraoral NAM technique. Materials and Methods: Twenty infants with complete unilateral cleft lip and palate were included and divided into two equal groups. Group A received the intraoral NAM technique, and Group B received the extraoral NAM technique. Pre- and postoperative extraoral and intraoral measurements were recorded.

Results: Groups A and B did not differ significantly in any extraoral or intraoral parameter.

Conclusion: The extraoral NAM technique is as effective as the intraoral NAM technique in achieving significant nasal and alveolar changes in complete unilateral cleft lip and palate patients. Additionally, it reduces the need for frequent hospital visits for activation and the stress associated with the insertion and removal of the intraoral NAM plate, thereby improving compliance.
\end{abstract}

Key words: Cleft lip and palate, Nasal and alveolar changes, Extraoral NAM technique, Nasal stent, Compliance

[paper submitted 2020. 12. 26 / accepted 2021. 3. 4]

\section{Introduction}

Cleft lip and palate (CLP) is one of the most common congenital deformities of the orofacial region ${ }^{1}$. It has a worldwide prevalence of 1.5 per 1,000 live births ${ }^{2}$ and a reported prevalence of 1.10 per 1,000 in India $^{3}$. CLP has a heterogeneous etiology with both environmental and genetic factors playing important roles ${ }^{4}$.

CLP can be present as an isolated anomaly or as part of a syndrome or comorbid condition. Unilateral clefts are nine times more prevalent than bilateral clefts, and males are pre-

\author{
Priyanka Bhaje \\ Department of Pediatric and Preventive Dentistry, Government Dental \\ College \& Hospital, Nagpur 440003, India \\ TEL: +91-07122743400 \\ E-mail:priyanka22bhaje@gmail.com \\ ORCID: https://orcid.org/0000-0003-1464-5478
}

(c) This is an open-access article distributed under the terms of the Creative Commons Attribution Non-Commercial License (http://creativecommons org/ licenses/by-nc/4.0/), which permits unrestricted non-commercial use, distribution, and reproduction in any medium, provided the original work is properly cited.

Copyright (C) 2021 The Korean Association of Oral and Maxillofacial Surgeons. dominantly affected, with a ratio of $2: 1$ (male:female) $)^{5}$. The usual clinical features of unilateral CLP are disruption in the anatomy of the nose, lip, palate, and alveolar arch. There is discontinuity of peri-oral tissues, and the affected side of the nose presents with increased width of the nostril and a depressed alar rim. The columella and nasal tip deviate to the normal/unaffected side. The maxillary alveolar segments are also displaced to the lateral side 6 .

These patients also suffer from various medical problems such as difficulty with feeding, swallowing, nasal regurgitation, hearing problems (due to palatal muscle abnormalities), and speech difficulties (because of nasal escape and articulation problems) ${ }^{7}$. Cleft defects thus have an adverse influence on health as well as the social integration of affected individuals. Despite early surgical intervention, residual deformity can remain through scarring and abnormal development of the face, which can result in functional and psychosocial problems.

The traditional treatment for CLP involved multiple surgical procedures, including secondary revision surgeries and 
alveolar bone grafting. Despite those multiple interventions, poor aesthetics remained a major concern. Any form of non-surgical treatment that can reduce the severity of this deformity in early life is thus highly desirable. The advent of the presurgical nasoalveolar molding (NAM) procedure has meant that the traditional secondary surgeries could be avoided while producing better results ${ }^{9}$.

The NAM procedure involves the use of intraoral plates, also called infant orthopedics, to mold cleft segments into the desired position. In 1999, Grayson et al. ${ }^{10}$ proposed combining the correction of cleft segment and nasal deformities into a single presurgical procedure. Grayson et al. ${ }^{10}$ proposed incorporating a nasal stent into the NAM appliance after the cleft width had been reduced to $<6 \mathrm{~mm}$, whereas Figueroa and Polley ${ }^{11}$ and Liou et al. ${ }^{12}$ incorporated the nasal stent from the beginning of the procedure because the alar rim has maximum laxity at that stage.

According to the theory of Matsuo et al. ${ }^{13}$, it is advisable to start NAM as early as possible to achieve the best possible outcome because the high maternal level of estrogen in infants in their first 6 weeks increases the hyaluronan content of cartilage, which increases the moldability of the nasal cartilage.

Although the NAM technique has numerous benefits, it has poor compliance for the following reasons ${ }^{14,15}$.

-Weekly or bi-weekly activation of these appliances requires frequent hospital visits, which places a financial burden on parents.

- Parents/caretakers feel anxious about the daily insertion and removal of the intraoral plate, which affects their compliance.

- Parents/caretakers often worry about complications of NAM, such as facial rashes caused by taping and oral ulceration from the intraoral plate.
- Other drawbacks include frequent appliance adjustments, lost or broken prostheses, and irritation of the soft and hard tissues that leads to gagging and choking.

To address those drawbacks of the intraoral NAM technique, we here compare an extraoral NAM technique with the older intraoral NAM technique.

\section{Materials and Methods}

This study was conducted from December 2017 to October 2019 in Government Dental College and Hospital, Nagpur, Maharashtra, Central India. After obtaining informed consent from parents, this randomized controlled trial was conducted on 20 infants with complete unilateral CLP (Veau's type 3). The infants were divided into two equal groups of 10. Group A received NAM using the intraoral technique, and Group $B$ received NAM using the extraoral technique. All included infants were younger than 7 days, non-syndromic, free of any systemic illness, and moderate to well-nourished (birth weight $\geq 2,500 \mathrm{~g}$ ).

In Group A, an impression of the CLP was taken using impression compound in a specialized acrylic impression tray. Caution was taken to avoid any airway obstruction. After the impression, the oral and nasal cavity was inspected for any residual impression material and trauma. A palatal/feeding plate was fabricated using a self-cure acrylic resin. The NAM technique used in this study is a modification of the original Liou NAM technique. It secures two 26-gauge stainless steel orthodontic wires that are placed bilaterally in the anterior portion of the palatal plate to the headcap of the infant to hold the intraoral plate in place. The nasal stent was fabricated using 24-gauge soft stainless-steel orthodontic wire in the shape of a lobe, and a bulb of self-cure acrylic resin (DPI-RR cold cure Acrylic repair material; Bombay Burmah Trading, Neh-
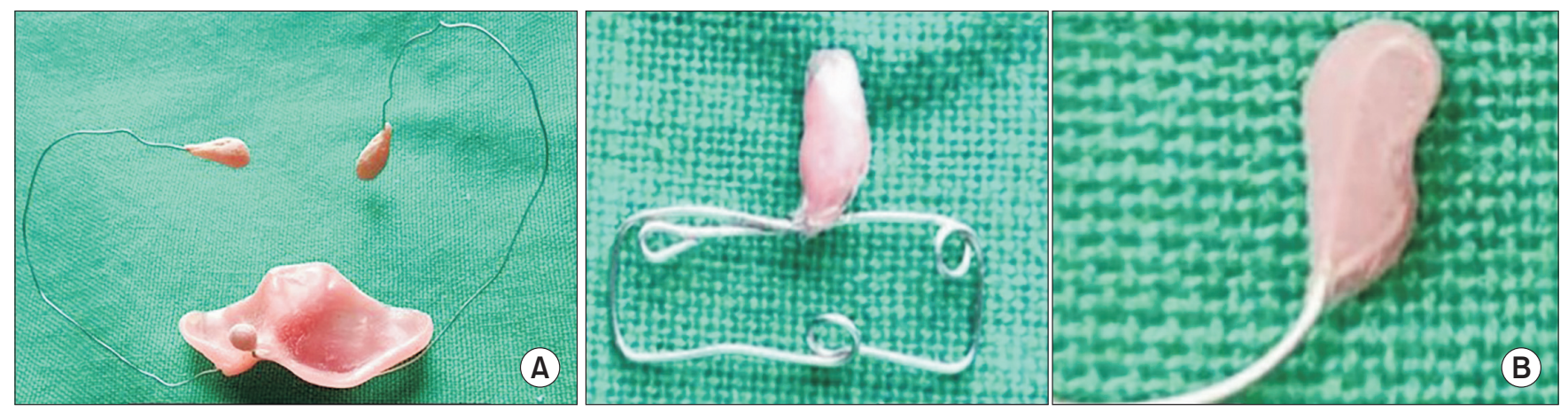

Fig. 1. Photograph of intraoral (A) and extraoral (B) nasoalveolar molding (NAM) appliances.

Ritesh Kalaskar et al: Comparative evaluation of nasal and alveolar changes in complete unilateral cleft lip and palate patients using intraoral and extraoral nasoalveolar molding techniques: randomized controlled trial. J Korean Assoc Oral Maxillofac Surg 2021 
ru Nagar, India) was placed over it to enable easy adjustment. (Fig. 1. A) The bulb of the nasal stent was placed inside the cleft nostril to lift the dome of the alar cartilage. After stabilizing the palatal plate and nasal stent, Tegaderm was applied to the skin, and the lips were approximated with 3M Steristrip adhesive tape (3M Health Care, St. Paul, MN, USA). Parents or caregivers were instructed to keep the plate in the mouth at all times, removing it only for cleaning. Subsequent follow-up visits were planned every 2 weeks to activate the appliance by adding $1 \mathrm{~mm}$ of soft acrylic resin to the lateral aspects of the larger segment and the acrylic bulb of the nasal stent to mold the alveolar and nasal cartilage, respectively.

In Group B, a similar procedure was followed to make an impression of the CLP. In this group, the NAM appliance had two parts. The first part was a feeding plate used only during feeding. The second part was an extraoral NAM appliance composed of a nasal stent made of 24 gauge soft stainless steel orthodontic wire and 3M Steri-strips as adhesive. The wire component was rectangular and approximately $25 \mathrm{~mm}$ long $\times 5 \mathrm{~mm}$ high.(Fig. 1. B) One end of the wire was shaped into a bilobed form resembling a kidney called the nasal stent. It was embedded in acrylic resin (DPI-RR cold cure) and lined with soft acrylic resin to make it easier for the newborn to endure. Before the insertion of the extraoral NAM appliance, Tegaderm was applied as a protective skin barrier. The lip segments were first approximated (put into place) with 3M Steri-strips. Afterward, the wire component was placed onto the taped prolabium of the upper lip and stabilized with another 3M Steri-strip. The upper lobe of the stent was positioned inside the nose, and the lower lobe was placed outside the nostril to mold the alar rim on the cleft side. Infants were brought to the hospital every 30 days to activate the appliance by adding $1 \mathrm{~mm}$ of soft acrylic resin to the upper lobe of the nasal stent to gently lift the alar dome cartilage.

In both groups, parents were instructed and trained to insert and remove the NAM appliance. NAM therapy was continued for 3 months in both groups, and parameters were evaluated preoperatively and postoperatively. The reference points (La, la', Np, np', Prn, Sn, Mac, mac, T1, T2, S, L, soft tissue cleft width) and linear measurements used to assess pre- and postoperative nasal and alveolar changes are described in Table 1.

Digital vernier calipers were used to take extraoral anthropometric measurements $(\mathrm{mm})$ : the soft tissue cleft width, total alar base width, columella length, nostril width on the non-cleft side, nostril width on the cleft side, nostril height on the non-cleft side, and nostril height on the cleft $\operatorname{side}^{16}$.(Fig. 2)
Table 1. Description of the reference points and linear measurements for cleft lip and palate

\begin{tabular}{|c|c|}
\hline & Description \\
\hline \multicolumn{2}{|l|}{ Reference point } \\
\hline $\mathrm{La}$ & $\begin{array}{l}\text { Most lateral aspect of the alar cartilage } \\
\text { on the non-cleft side }\end{array}$ \\
\hline la' & $\begin{array}{l}\text { Most lateral aspect of the alar cartilage } \\
\text { on the cleft side }\end{array}$ \\
\hline $\mathrm{Np}$ & $\begin{array}{l}\text { Highest point of the nostril from the la } \\
\text { point }\end{array}$ \\
\hline$n p^{\prime}$ & $\begin{array}{l}\text { Highest point of the nostril from the la' } \\
\text { point }\end{array}$ \\
\hline Prn & $\begin{array}{l}\text { Pronasale - highest point of the } \\
\text { columella }\end{array}$ \\
\hline Sn & $\begin{array}{l}\text { Subnasale - point of intersection } \\
\text { between the columella and the } \\
\text { philtrum }\end{array}$ \\
\hline Mac & $\begin{array}{l}\text { Medial alar cartilage on the non-cleft } \\
\text { side }\end{array}$ \\
\hline $\operatorname{mac}^{\prime}$ & Medial alar cartilage on the cleft side \\
\hline T1 & $\begin{array}{l}\text { Most posterior point on the smaller } \\
\text { segment }\end{array}$ \\
\hline $\mathrm{T} 2$ & $\begin{array}{l}\text { Most posterior point on the larger } \\
\text { segment }\end{array}$ \\
\hline $\mathrm{S}$ & $\begin{array}{l}\text { Midpoint of the anterior aspect of the } \\
\text { smaller alveolar ridge }\end{array}$ \\
\hline $\mathrm{L}$ & $\begin{array}{l}\text { Midpoint of the anterior aspect of the } \\
\text { larger alveolar ridge }\end{array}$ \\
\hline $\begin{array}{l}\text { Soft tissue cleft } \\
\text { width }\end{array}$ & $\begin{array}{l}\text { Distance between the most anterior } \\
\text { aspects of the cleft segments }\end{array}$ \\
\hline \multicolumn{2}{|l|}{ Linear measurements } \\
\hline $\begin{array}{l}\text { Total alar base } \\
\text { width (la-la') }\end{array}$ & $\begin{array}{l}\text { Distance between the most lateral aspect } \\
\text { of the right alar cartilage and the most } \\
\text { lateral aspect of left alar cartilage }\end{array}$ \\
\hline $\begin{array}{l}\text { Columella length } \\
\text { (sn-prn) }\end{array}$ & $\begin{array}{l}\text { Distance between the intersection of the } \\
\text { columella and the philtrum and the } \\
\text { highest point of the columella }\end{array}$ \\
\hline $\begin{array}{l}\text { Nostril height on } \\
\left.\text { cleft side (la' }-\mathrm{np}^{\prime}\right)\end{array}$ & $\begin{array}{l}\text { Distance between the highest peak (np') } \\
\text { of the nostril and most lateral aspect of } \\
\text { the alar cartilage on the cleft side (la') }\end{array}$ \\
\hline $\begin{array}{l}\text { Nostril width on } \\
\text { cleft side } \\
\left(\text { la' }^{\prime}-\mathrm{mac}^{\prime}\right)\end{array}$ & $\begin{array}{l}\text { Distance from the mac' point to the } \\
\text { most lateral aspect }\left(\text { la }^{\prime}\right) \text { of the alar } \\
\text { cartilage on the cleft side }\end{array}$ \\
\hline $\begin{array}{l}\text { Nostril height on } \\
\text { non-cleft side } \\
\text { (la-np) }\end{array}$ & $\begin{array}{l}\text { Distance between the highest peak (np) } \\
\text { of the nostril and the most lateral } \\
\text { aspect of the alar cartilage on the non- } \\
\text { cleft side (la) }\end{array}$ \\
\hline $\begin{array}{l}\text { Nostril width on } \\
\text { non-cleft side } \\
\text { (la-mac) }\end{array}$ & $\begin{array}{l}\text { Distance from the mac point to the most } \\
\text { lateral aspect (la) of the alar cartilage } \\
\text { on the non-cleft side }\end{array}$ \\
\hline $\begin{array}{l}\text { Anterior alveolar } \\
\text { cleft width (S-L) }\end{array}$ & $\begin{array}{l}\text { Distance between the most anterior } \\
\text { aspects of the alveolar ridges }\end{array}$ \\
\hline $\begin{array}{l}\text { Larger segment } \\
\text { length (L-T2) }\end{array}$ & $\begin{array}{l}\text { Distance between the most prominent } \\
\text { point from the anterior aspect (point } \mathrm{L} \text { ) } \\
\text { to the most prominent point from the } \\
\text { posterior aspect of the larger segment } \\
\text { (point } \mathrm{T} 2 \text { ) }\end{array}$ \\
\hline $\begin{array}{l}\text { Smaller segment } \\
\text { length (S-T1) }\end{array}$ & $\begin{array}{l}\text { Distance between the most prominent } \\
\text { point from the anterior aspect (point } S \text { ) } \\
\text { to the most prominent point from the } \\
\text { posterior aspect of the smaller segment } \\
\text { (point } \mathrm{T} 1 \text { ) }\end{array}$ \\
\hline
\end{tabular}

Ritesh Kalaskar et al: Comparative evaluation of nasal and alveolar changes in complete unilateral cleft lip and palate patients using intraoral and extraoral nasoalveolar molding techniques: randomized controlled trial. J Korean Assoc Oral Maxillofac Surg 2021 

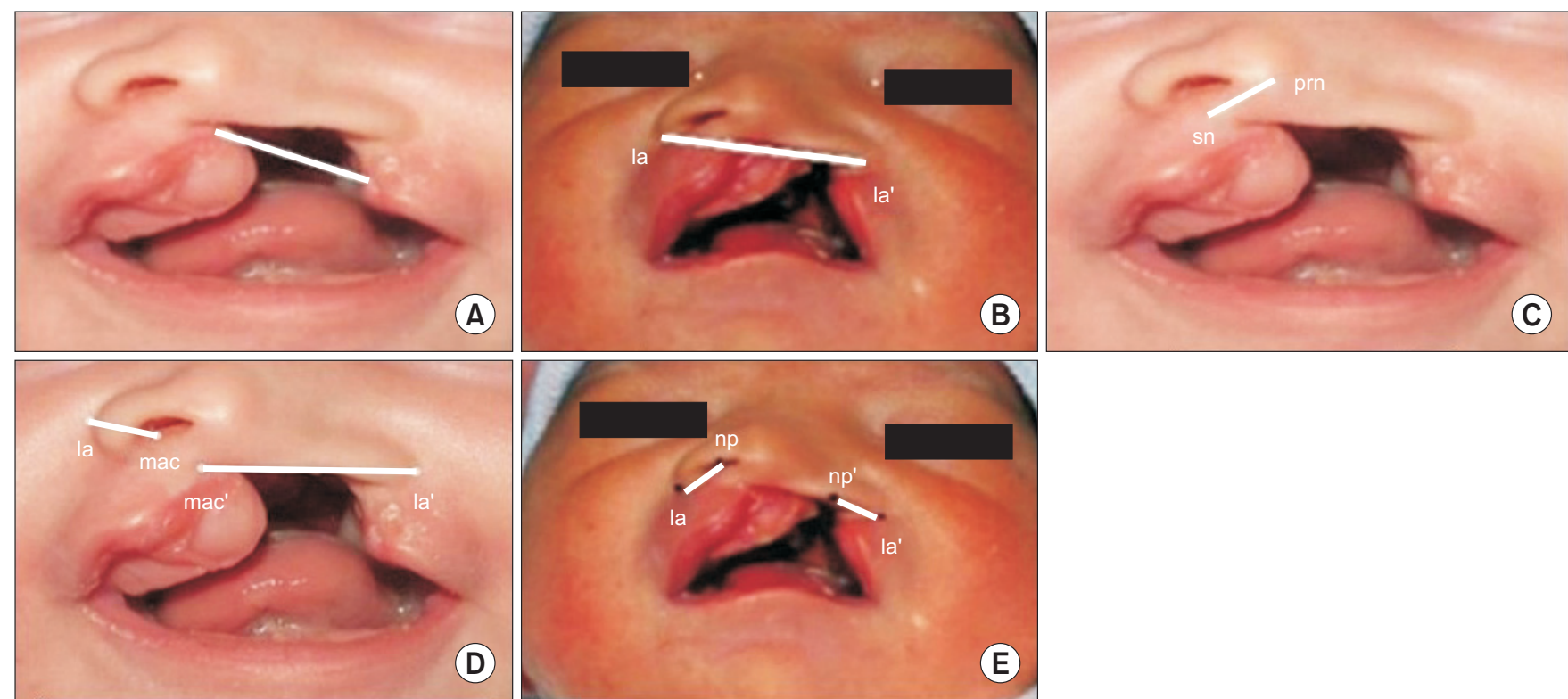

Fig. 2. Photograph showing extraoral anthropometric measurements of cleft lip and palate. A. Soft tissue cleft width. B. Total alar base width. C. Columella length. D. Nostril width on cleft and non-cleft side. E. Nostril height on cleft and on-cleft side.

Ritesh Kalaskar et al: Comparative evaluation of nasal and alveolar changes in complete unilateral cleft lip and palate patients using intraoral and extraoral nasoalveolar molding techniques: randomized controlled trial. J Korean Assoc Oral Maxillofac Surg 2021
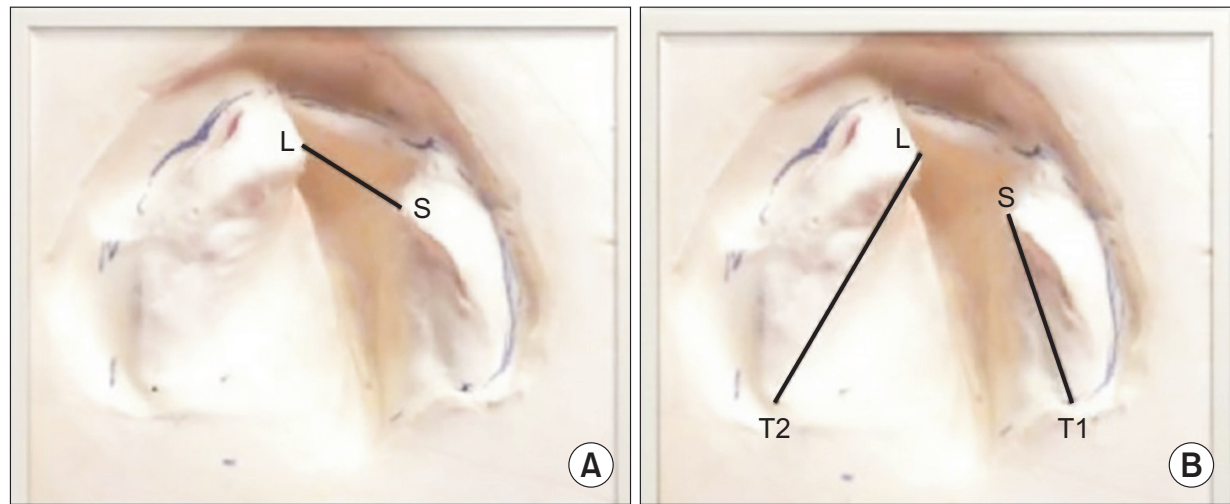

Fig. 3. Photograph showing intraoral measurements on cleft lip and palate cast. A. Anterior alveolar cleft width. B. Length of larger and smaller segment.

Ritesh Kalaskar et al: Comparative evaluation of nasal and alveolar changes in complete unilateral cleft lip and palate patients using intraoral and extraoral nasoalveolar molding techniques: randomized controlled trial. J Korean Assoc Oral Maxillofac Surg 2021
Similarly, intraoral measurements $(\mathrm{mm})$ were recorded on the CLP cast: the anterior alveolar cleft width, length of the larger segment, and length of the smaller segment ${ }^{17}$.(Fig. 3)

Statistical analyses were done using the Shapiro-Wilk test. Intergroup comparisons were made using the $t$-test. Intragroup comparisons were done using paired $t$-test. Frequency comparisons of variables within groups were made using the chi-square test. The analysis was performed using IBM SPSS Statistics for Windows (ver. 22.0; IBM, Armonk, NY, USA). Differences between groups were considered significant at $P<0.05$.
Table 2. Demographic description of the cleft lip and palate infants

\begin{tabular}{lcc} 
Variable & $\begin{array}{c}\text { Intraoral } \\
\text { NAM group } \\
\text { (Group A) }\end{array}$ & $\begin{array}{c}\text { Extraoral } \\
\text { NAM group } \\
\text { (Group B) }\end{array}$ \\
\hline No. of patients & 10 & 10 \\
Male (n) & 6 & 7 \\
Female (n) & 4 & 3 \\
Initial age (day) & $4.2 \pm 1.8$ & $3.9 \pm 1.7$ \\
Age posttreatment (day) & 93 & 91 \\
\hline
\end{tabular}

(NAM: nasoalveolar molding)

Values are presented as number only or mean \pm standard deviation. Ritesh Kalaskar et al: Comparative evaluation of nasal and alveolar changes in complete unilateral cleft lip and palate patients using intraoral and extraoral nasoalveolar molding techniques: randomized controlled trial. J Korean Assoc Oral Maxillofac Surg 2021

\section{Results}

Among the 20 infants in groups A and B, 65\% were male, and $60 \%$ had CLP on the left side. The mean age of the in- 

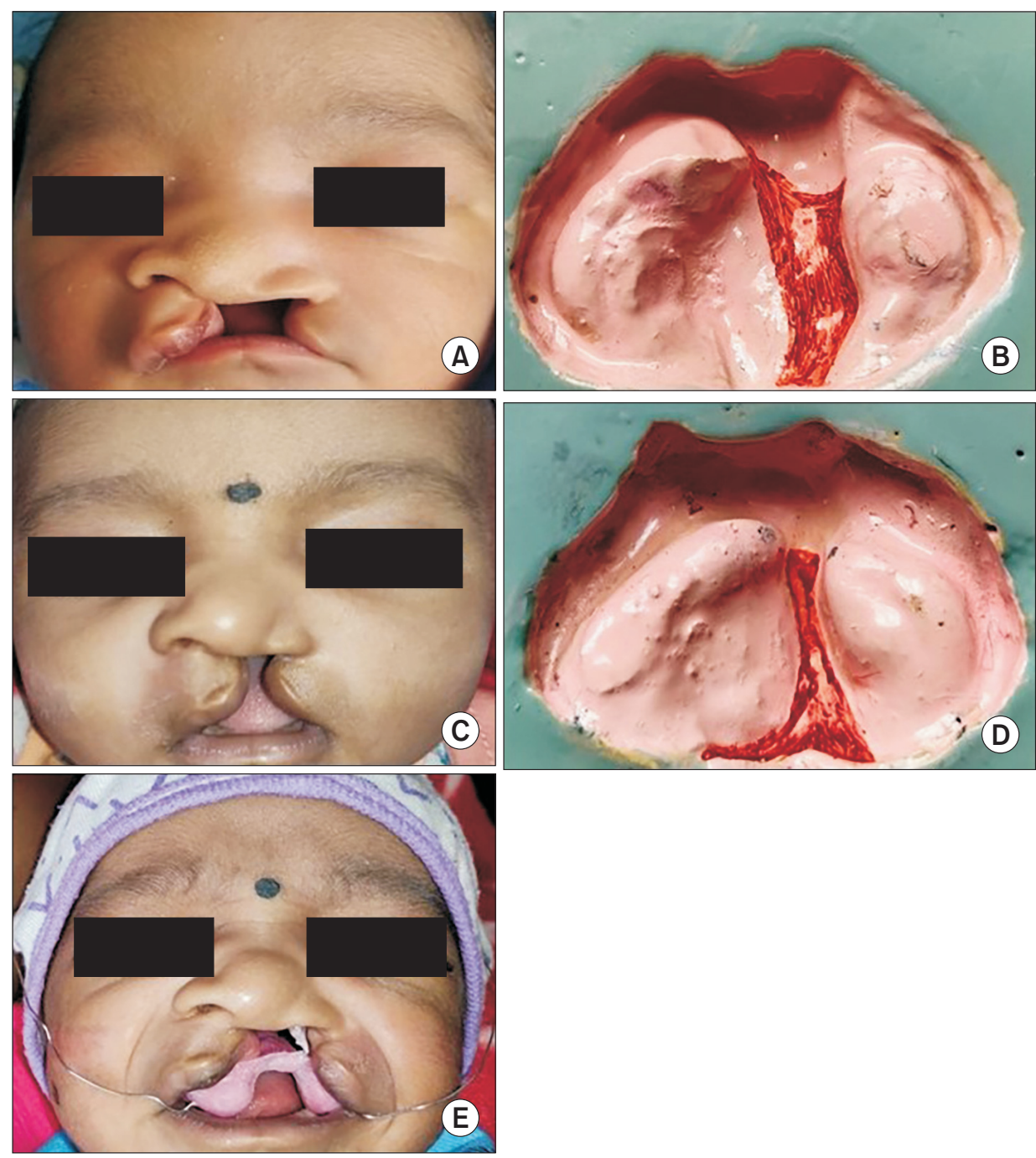

Fig. 4. Photograph showing preand postoperative nasal and alveolar changes in Group A. A. Preoperative photograph. B. Preoperative cleft lip and palate (CLP) cast. C. Postoperative photograph. D. Postoperative CLP cast. E. Appliance in place.

Ritesh Kalaskar et al: Comparative evaluation of nasal and alveolar changes in complete unilateral cleft lip and palate patients using intraoral and extraoral nasoalveolar molding techniques: randomized controlled trial. J Korean Assoc Oral Maxillofac Surg 2021

Table 3. Distribution and intragroup comparison of all variables (preoperative and postoperative measurements) in Group A

\begin{tabular}{|c|c|c|c|c|c|c|}
\hline Parameter & & Mean & $\mathrm{SD}$ & $\begin{array}{c}\text { Mean } \\
\text { difference }\end{array}$ & $\begin{array}{c}\text { SD of } \\
\text { difference }\end{array}$ & $P$-value \\
\hline Soft tissue cleft width (mm) & $\begin{array}{l}\text { Pre } \\
\text { Post }\end{array}$ & $\begin{array}{l}9.16 \\
5.32\end{array}$ & $\begin{array}{l}3.23 \\
2.82\end{array}$ & -3.84 & 2.33 & $0.001^{* * *}$ \\
\hline Total alar base width (mm) & $\begin{array}{l}\text { Pre } \\
\text { Post }\end{array}$ & $\begin{array}{l}27.16 \\
24.10\end{array}$ & $\begin{array}{l}4.63 \\
5.14\end{array}$ & -3.06 & 3.83 & $0.033^{*}$ \\
\hline Columella length (mm) & $\begin{array}{l}\text { Pre } \\
\text { Post }\end{array}$ & $\begin{array}{l}4.94 \\
6.90\end{array}$ & $\begin{array}{l}1.56 \\
2.06\end{array}$ & 1.96 & 1.69 & $0.005 * *$ \\
\hline Nostril height on cleft side (mm) & $\begin{array}{l}\text { Pre } \\
\text { Post }\end{array}$ & $\begin{array}{l}6.24 \\
7.47\end{array}$ & $\begin{array}{l}2.74 \\
2.99\end{array}$ & 1.23 & 0.74 & $0.001 * *$ \\
\hline Nostril width on cleft side (mm) & $\begin{array}{l}\text { Pre } \\
\text { Post }\end{array}$ & $\begin{array}{l}17.21 \\
13.31\end{array}$ & $\begin{array}{l}2.79 \\
2.95\end{array}$ & -3.90 & 2.75 & $0.002 * *$ \\
\hline Nostril height on non-cleft side (mm) & $\begin{array}{l}\text { Pre } \\
\text { Post }\end{array}$ & $\begin{array}{l}5.75 \\
7.24\end{array}$ & $\begin{array}{l}2.20 \\
2.21\end{array}$ & 1.49 & 0.97 & $0.001 * *$ \\
\hline Nostril width on non-cleft side (mm) & $\begin{array}{l}\text { Pre } \\
\text { Post }\end{array}$ & $\begin{array}{l}7.50 \\
9.34\end{array}$ & $\begin{array}{l}1.71 \\
1.05\end{array}$ & 1.84 & 1.37 & $0.002 * *$ \\
\hline Anterior alveolar cleft width (mm) & $\begin{array}{l}\text { Pre } \\
\text { Post }\end{array}$ & $\begin{array}{l}9.92 \\
6.00\end{array}$ & $\begin{array}{l}2.73 \\
1.79\end{array}$ & -3.92 & 2.44 & $0.001 * *$ \\
\hline Length of larger segment (mm) & $\begin{array}{l}\text { Pre } \\
\text { Post }\end{array}$ & $\begin{array}{l}25.29 \\
29.92\end{array}$ & $\begin{array}{l}2.65 \\
3.76\end{array}$ & 4.63 & 3.14 & $0.001 * *$ \\
\hline Length of smaller segment (mm) & $\begin{array}{l}\text { Pre } \\
\text { Post }\end{array}$ & $\begin{array}{l}17.77 \\
21.43\end{array}$ & $\begin{array}{l}1.46 \\
2.98\end{array}$ & 3.66 & 2.38 & $0.001 * *$ \\
\hline
\end{tabular}

(SD: standard deviation)

$* P<0.05, * * P<0.01$.

${ }^{1}$ By $t$-test.

Ritesh Kalaskar et al: Comparative evaluation of nasal and alveolar changes in complete unilateral cleft lip and palate patients using intraoral and extraoral nasoalveolar molding techniques: randomized controlled trial. J Korean Assoc Oral Maxillofac Surg 2021 

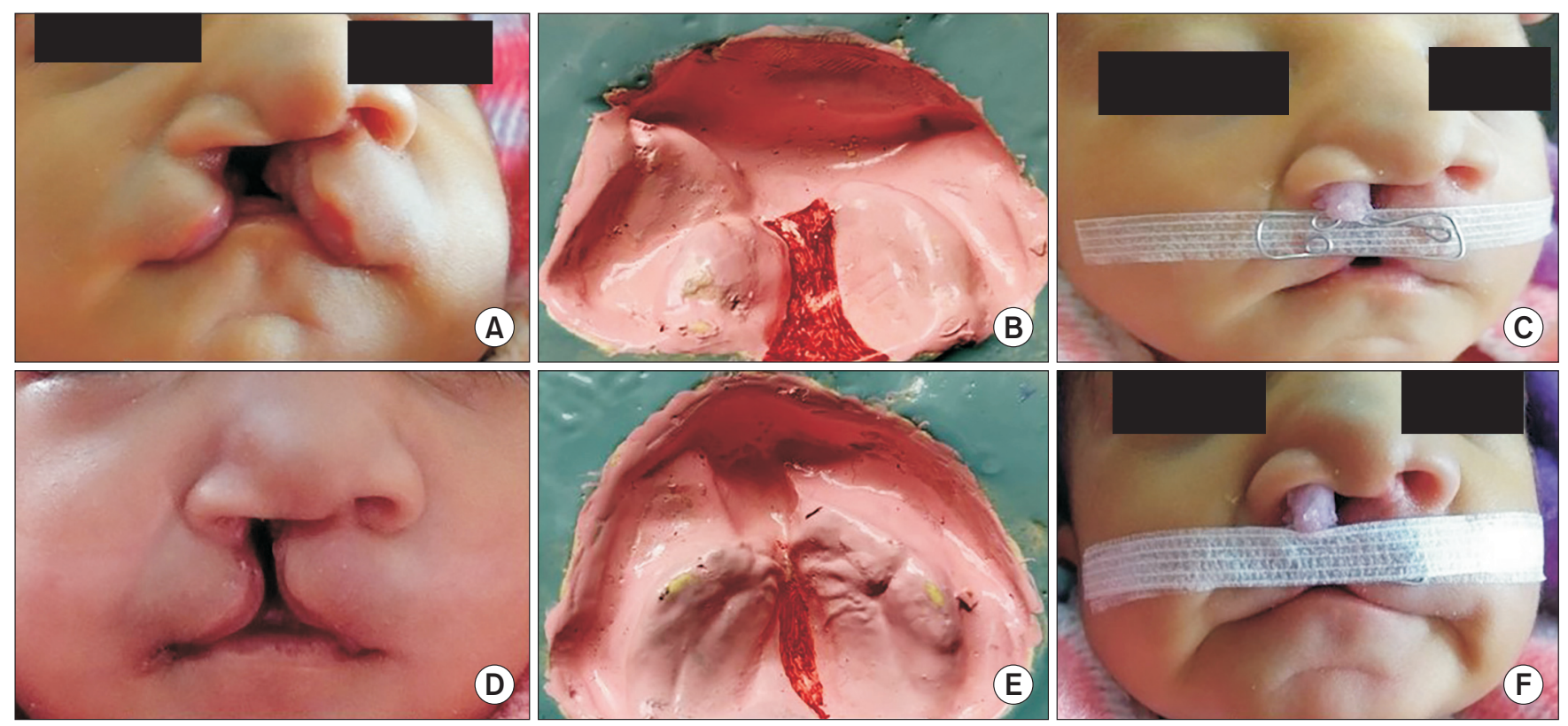

Fig. 5. Photograph showing pre and postoperative nasal and alveolar changes in Group B. A. Preoperative photograph. B. Preoperative cleft lip and palate (CLP) cast. C. Appliance in place. D. Postoperative photograph. E. Postoperative CLP cast. F. Appliance in place. Ritesh Kalaskar et al: Comparative evaluation of nasal and alveolar changes in complete unilateral cleft lip and palate patients using intraoral and extraoral nasoalveolar molding techniques: randomized controlled trial. J Korean Assoc Oral Maxillofac Surg 2021

fants at the time NAM therapy began was $4.2 \pm 1.8$ days in

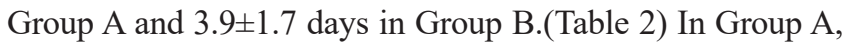
significant differences in extraoral and intraoral parameters were observed postoperatively.(Fig. 4) Among the extraoral anthropometric parameters, soft tissue cleft width, total alar base width, and nostril width on the cleft side decreased, whereas nostril width on the non-cleft side, nostril height on both sides, and the columella length increased significantly after intraoral NAM therapy. Intraoral measurements on the CLP cast showed a significant decrease in the anterior alveolar cleft width and a significant increase in the length of both the larger and smaller segments postoperatively.(Table 3)

In Group B, both extraoral anthropometric measurements and intraoral measurements on the CLP cast changed significantly after extraoral NAM therapy.(Fig. 5) Among the extraoral parameters, soft tissue cleft width, total alar base width, and nostril width on the cleft side all decreased after NAM therapy, whereas nostril width on the non-cleft side, nostril height on both sides, and columella length all increased significantly. Measurements on the CLP cast showed a significant decrease in the anterior alveolar cleft width and an increase in the length of both the larger and smaller segments.(Table 4)

The intergroup comparison of mean differences in all the extraoral anthropometric measurements (soft tissue cleft width, total alar base width, nostril width on both sides, nos- tril height on both sides, and columella length) showed no statistically significant differences. Similarly, the intraoral measurements on the CLP cast showed no statistically significant differences between the groups in the anterior alveolar cleft width or the length of the larger and smaller segments. (Table 5)

\section{Discussion}

CLP is a common congenital deformity that affects aesthetics, speech, and hearing ${ }^{18}$. Various surgical procedures have been used to correct it, but the results were unsatisfactory to both patients and surgeons ${ }^{19}$. One commonly encountered problem is finding a way to restore the correct anatomy of the nose and lip while minimizing scar formation. With a wide cleft deformity, surgical treatment alone can lead to the formation of a thick scar at the base of the nose and columella and a deviated nasal tip ${ }^{10}$. Therefore, presurgical procedures have gained importance in making it possible to achieve a finer surgical scar, good nasal tip projection, and a precisely molded nasolabial complex ${ }^{20}$.

Historically, various presurgical procedures have been used for non-surgical correction of CLP. Franco developed a head cup as an extraoral approach to reducing the cleft gap, whereas Hoffman in the 17th century designed a head cup with a facial extension over the cheeks and lips to press the premax- 
Table 4. Distribution and intragroup comparison of all variables (preoperative and postoperative measurements) in Group B

\begin{tabular}{|c|c|c|c|c|c|c|}
\hline Parameter & & Mean & $\mathrm{SD}$ & $\begin{array}{c}\text { Mean } \\
\text { difference }\end{array}$ & $\begin{array}{c}\text { SD of } \\
\text { difference }\end{array}$ & $P$-value \\
\hline Soft tissue cleft width (mm) & $\begin{array}{l}\text { Pre } \\
\text { Post }\end{array}$ & $\begin{array}{r}10.88 \\
5.95\end{array}$ & $\begin{array}{l}3.03 \\
2.99\end{array}$ & -4.93 & 2.57 & $0.000^{* * *}$ \\
\hline Total alar base width $(\mathrm{mm})$ & $\begin{array}{l}\text { Pre } \\
\text { Post }\end{array}$ & $\begin{array}{l}30.01 \\
27.23\end{array}$ & $\begin{array}{l}1.38 \\
1.64\end{array}$ & -2.78 & 1.48 & $0.000 * *$ \\
\hline Columella length (mm) & $\begin{array}{l}\text { Pre } \\
\text { Post }\end{array}$ & $\begin{array}{l}4.59 \\
6.89\end{array}$ & $\begin{array}{l}1.88 \\
1.92\end{array}$ & 2.30 & 1.46 & $0.001 * *$ \\
\hline Nostril height on cleft side (mm) & $\begin{array}{l}\text { Pre } \\
\text { Post }\end{array}$ & $\begin{array}{l}5.78 \\
7.89\end{array}$ & $\begin{array}{l}2.71 \\
2.47\end{array}$ & 2.11 & 1.61 & $0.002 * *$ \\
\hline Nostril width on cleft side (mm) & $\begin{array}{l}\text { Pre } \\
\text { Post }\end{array}$ & $\begin{array}{l}18.56 \\
15.05\end{array}$ & $\begin{array}{l}3.68 \\
3.77\end{array}$ & -3.51 & 2.42 & $0.001 * *$ \\
\hline Nostril height on non-cleft side (mm) & $\begin{array}{l}\text { Pre } \\
\text { Post }\end{array}$ & $\begin{array}{l}6.12 \\
9.19\end{array}$ & $\begin{array}{l}1.79 \\
1.99\end{array}$ & 3.07 & 1.64 & $0.000 * *$ \\
\hline Nostril width on non-cleft side (mm) & $\begin{array}{l}\text { Pre } \\
\text { Post }\end{array}$ & $\begin{array}{l}7.35 \\
9.08\end{array}$ & $\begin{array}{l}1.99 \\
2.07\end{array}$ & 1.73 & 0.64 & $0.000 * *$ \\
\hline Anterior alveolar cleft width (mm) & $\begin{array}{l}\text { Pre } \\
\text { Post }\end{array}$ & $\begin{array}{l}9.86 \\
4.98\end{array}$ & $\begin{array}{l}2.25 \\
2.11\end{array}$ & -4.88 & 2.38 & $0.000 * *$ \\
\hline Length of larger segment (mm) & $\begin{array}{l}\text { Pre } \\
\text { Post }\end{array}$ & $\begin{array}{l}24.97 \\
28.91\end{array}$ & $\begin{array}{l}4.38 \\
5.07\end{array}$ & 3.94 & 2.67 & $0.001 * *$ \\
\hline Length of smaller segment $(\mathrm{mm})$ & $\begin{array}{l}\text { Pre } \\
\text { Post }\end{array}$ & $\begin{array}{l}18.45 \\
23.61\end{array}$ & $\begin{array}{l}3.74 \\
4.36\end{array}$ & 5.16 & 3.25 & $0.001 * *$ \\
\hline
\end{tabular}

(SD: standard deviation)

$* * P<0.01$.

${ }^{1}$ By $t$-test.

Ritesh Kalaskar et al: Comparative evaluation of nasal and alveolar changes in complete unilateral cleft lip and palate patients using intraoral and extraoral nasoalveolar molding techniques: randomized controlled trial. J Korean Assoc Oral Maxillofac Surg 2021

Table 5. Distribution and intergroup comparison of all variables (preoperative and postoperative measurements) between Group A and Group B

\begin{tabular}{|c|c|c|c|c|c|c|c|c|c|}
\hline & \multicolumn{4}{|c|}{ Group A } & \multicolumn{4}{|c|}{ Group B } & \multirow[b]{2}{*}{$P$-value } \\
\hline & $\begin{array}{l}\text { Preop } \\
\text { (Pr) }\end{array}$ & $\begin{array}{l}\text { Postop } \\
\text { (Po) }\end{array}$ & $\begin{array}{c}\text { Mean } \\
\text { difference } \\
(\mathrm{Po}-\mathrm{Pr})\end{array}$ & $\begin{array}{c}\text { SD of } \\
\text { difference }\end{array}$ & $\begin{array}{c}\text { Preop } \\
\text { (Pr) }\end{array}$ & $\begin{array}{l}\text { Postop } \\
\text { (Po) }\end{array}$ & $\begin{array}{c}\text { Mean } \\
\text { difference } \\
\text { (Po-Pr) }\end{array}$ & $\begin{array}{c}\text { SD of } \\
\text { difference }\end{array}$ & \\
\hline Soft tissue cleft width (mm) & 9.16 & 5.32 & -3.84 & 2.33 & 10.88 & 5.95 & -4.93 & 2.57 & 0.33 \\
\hline Total alar base width (mm) & 27.16 & 24.10 & -3.06 & 3.83 & 30.01 & 27.23 & -2.78 & 1.48 & 0.83 \\
\hline Columella length (mm) & 4.94 & 6.90 & 1.96 & 1.69 & 4.59 & 6.89 & 2.30 & 1.46 & 0.64 \\
\hline Nostril height on cleft side $(\mathrm{mm})$ & 6.24 & 7.47 & 1.23 & 0.74 & 5.78 & 7.89 & 2.11 & 1.61 & 0.13 \\
\hline Nostril width on cleft side (mm) & 17.21 & 13.31 & -3.90 & 2.76 & 18.56 & 15.05 & -3.51 & 2.42 & 0.74 \\
\hline Nostril height on non-cleft side (mm) & 5.75 & 7.24 & 1.49 & 0.97 & 6.12 & 9.19 & 3.07 & 1.64 & 0.02 \\
\hline Nostril width on non-cleft side (mm) & 7.50 & 9.34 & 1.84 & 1.37 & 7.35 & 9.08 & 1.73 & 0.64 & 0.82 \\
\hline Anterior alveolar cleft width (mm) & 9.92 & 6.00 & -3.92 & 2.44 & 9.86 & 4.98 & -4.88 & 2.38 & 0.39 \\
\hline Length of larger segment (mm) & 25.29 & 29.92 & 4.63 & 3.14 & 24.97 & 28.91 & 3.94 & 2.67 & 0.60 \\
\hline Length of smaller segment $(\mathrm{mm})$ & 17.77 & 21.43 & 3.66 & 2.38 & 18.45 & 23.61 & 5.16 & 3.25 & 0.25 \\
\hline
\end{tabular}

(SD: standard deviation)

${ }^{1}$ By $t$-test.

Ritesh Kalaskar et al: Comparative evaluation of nasal and alveolar changes in complete unilateral cleft lip and palate patients using intraoral and extraoral nasoalveolar molding techniques: randomized controlled trial. J Korean Assoc Oral Maxillofac Surg 2021

illa backward. In 1844, Hullihan described the use of a facial adhesive strap across the cleft before surgical closure ${ }^{10}$. In the modern era, McNeil ${ }^{21}$ developed an intraoral plate similar to an obturator that effectively reduced the size of the alveolar and hard palate cleft. The disadvantage of those presurgical orthopedic appliances was that only the alveolar ridges were molded, not the nasal deformity. In 1991, Dogliotti et al. ${ }^{22}$ described presurgical neonatal nasal remodeling with a modified intraoral plate. Later, Grayson et al. ${ }^{10}$ popularized that method as presurgical NAM. They incorporated a nasal stent after reducing the cleft width to $5 \mathrm{~mm}$, but Figueroa et al. ${ }^{11}$ and Liou et al. ${ }^{12}$ incorporated the stent from the beginning of the NAM procedure. Since then, many modifications have been proposed by different authors. But irrespective of the modifications proposed, the original problems with compliance, which had several causes, persisted.

The intraoral NAM appliance require multiple hospital visits and daily maintenance, which creates a financial burden for families. Second, the intraoral plate sometimes leads to soft and hard tissue irritation, causing ulceration and fungal infections. The inconvenience of multiple lip taping steps and the need for appropriate appliance positioning prompts many 
parents to discontinue the treatment ${ }^{23}$. Similarly, the appliance has a tendency to dislodge, which can lead to airway obstruction $^{21}$. Therefore, it is important to formulate a different protocol for NAM. In this study, we compared extraoral and intraoral NAM approaches using various extraoral anthropometric and intraoral CLP parameters.

Infants younger than 7 days were included in this study because various authors have advocated for early intervention as a way to achieve the best possible clinical outcomes. Shetty et al. ${ }^{24}$ reported that the first 6 weeks of life is the window during which cartilage is highly malleable and soft. Of the 20 infants included in this study, 65.0\% (13) were male, and $35.0 \%$ (7) were female. A literature search revealed high male predominance in CLP (male:female ratio, 60:40) ${ }^{25}$. The male predominance in this study is thus in accordance with the incidence reported in the literature. One possible reason for male predominance could be the prevalence of female feticide and a lack of hospital care accessibility for female cleft patients in India ${ }^{26}$.

In this study, most of the infants (60\%) had left sided CLP, which is also in accordance with the reported literature worldwide. The study conducted by Shapira et al. ${ }^{25}$ similarly found that $59 \%$ of affected infants had left sided CLP. A suggested reason for this sidedness is the lower arterial pressure of the internal carotid artery on the left side compared with the right side. Apart from that, animal studies have shown that the left palatal side takes longer to rotate in the horizontal position, leaving this side susceptible to developmental interruption ${ }^{27}$.

In our evaluation of extraoral anthropometric measurements, we found a statistically significant reduction in the mean soft tissue cleft width, with a mean difference of 3.8 $\mathrm{mm}$. A study conducted by Monasterio et al. ${ }^{28}$ showed a similar result in reducing the mean soft tissue cleft width using Grayson's NAM technique. Total alar base width is another important parameter that changes significantly after NAM therapy. In this study, the mean total alar base width decreased from $27.1 \mathrm{~mm}$ preoperatively to $24.1 \mathrm{~mm}$ postoperatively, for a mean reduction of $3 \mathrm{~mm}$. The literature contains mixed results in reducing the width of the total alar base. A study conducted by Zuhaib et al. ${ }^{29}$ reported a mean reduction of $4.04 \mathrm{~mm}$ using Liou's technique. That observation is similar to our result when using a similar NAM technique. However, the study of Koya et al. ${ }^{17}$ found a significant increase in the mean total alar base width from 27 to $30 \mathrm{~mm}$, which is contradictory to our finding. This difference could be due to an ineffective lip taping procedure. In this study, effective lip taping helped to reduce the total alar base width.
Columella length is another factor that contributes to facial aesthetics. In this study, the mean columella length increased from $4.94 \mathrm{~mm}$ preoperatively to $6.9 \mathrm{~mm}$ postoperatively. This observation is in accordance with the studies of Zuhaib et al. ${ }^{29}$ and Liou et al. ${ }^{12}$, whereas the study of Gomez et al. ${ }^{30}$ showed an increase in columella length of $1.7 \mathrm{~mm}$. According to Gomez et al. ${ }^{30}$, only severe cases of CLP require lip taping, whereas in milder cases, lip taping does not have much influence on the columella length. Nostril width and nostril height (on both the cleft and non-cleft sides) are also important parameters in assessing facial aesthetics. After NAM therapy, the nostril width on the cleft side should decrease, the nostril width on the non-cleft side should increase, and the nostril height on both sides (cleft and non-cleft) should increase. In this study, the nostril width on the cleft side decreased significantly, and the nostril height on both sides increased. Similar observations were reported by Liou et al. ${ }^{12}$ and Pai et al. ${ }^{31}$. A recent study by Singh et al. ${ }^{32}$ found significant improvement in nasal symmetry both vertically (nostril height and columella length) and horizontally (nostril width and nostril basal width) using both the Figueroa and Grayson NAM techniques.

The success of NAM therapy correlates directly with a reduction in the anterior alveolar cleft width. We found a significant reduction in the anterior alveolar cleft width of $3.92 \mathrm{~mm}$ using intraoral NAM technique (Group A). A study conducted by Koya et al. ${ }^{17}$ reported a decrease in the mean anterior alveolar cleft width of $6.7 \mathrm{~mm}$. Furthermore, Zuhaib et al. ${ }^{29}$, Patel and Goyal ${ }^{33}$, and Pai et al. ${ }^{31}$ reported mean reductions in the anterior alveolar cleft width of $4.07 \mathrm{~mm}$ after 4 months, $7 \mathrm{~mm}$ after 5 months, and $5.8 \mathrm{~mm}$ after 4 months, respectively. The larger reductions in those studies, compared with our results, can be attributed to the increased duration of NAM treatment in those studies.

Another factor that contributes to the success of NAM therapy is the growth of the larger and smaller segments. In this study, the length of larger and smaller segments increased by $4.63 \mathrm{~mm}$ and $3.66 \mathrm{~mm}$, respectively.(Table 3, Fig. 4) Similar increases in linear measurements were noted with the use of passive NAM therapy by Prahl et al. ${ }^{34}$ and Mishima et al. ${ }^{35}$. Sabarinath et al. ${ }^{36}$, who treated unilateral CLP infants with Grayson NAM therapy, also reported an increase in the growth of the larger and smaller segments. These observations indicate that NAM therapy does not disturb the growth of the maxillary segments. Thus, it can be said that NAM therapy acts mainly by redirecting the alveolar segment rather than restricting its growth. The intraoral NAM technique 
showed significant changes after NAM therapy.

To correct the drawbacks of the intraoral NAM technique, an extraoral NAM technique was designed. It is a new approach to effectively mold the nasal cartilage and alveolar segments in unilateral CLP patients. However, our literature review revealed very few studies analyzing the changes produced by the extraoral NAM technique.

In this study, the extraoral approach significantly reduced the soft tissue cleft width from $10.8 \mathrm{~mm}$ preoperatively to 5.9 $\mathrm{mm}$ postoperatively, for a mean reduction of $4.9 \mathrm{~mm}$. The study of Monasterio et al. ${ }^{28}$ reported a reduction of $4.1 \mathrm{~mm}$ in soft tissue cleft width when using the extraoral approach, and similar observations were documented by Wang et al. ${ }^{16}$ and Doruk and Kiliç ${ }^{37}$.

In CLP, the wide nostril base and separated lip segments substantially increase the total alar base. Presurgical NAM therapy helps to reduce that alar base width by moving the cleft segments towards each other. We observed a mean reduction of $2.78 \mathrm{~mm}$ in the total alar base width using the extraoral approach. Wang et al. ${ }^{16}$ reported a mean reduction of $1.17 \mathrm{~mm}$ in total alar base width; however, that was a case report, so those observations cannot be compared with the current clinical trial. To generalize our observation, further studies of the extraoral approach are needed. In this current study, the mean columella length was increased by $2.3 \mathrm{~mm}$. The study of Monasterio et al. ${ }^{28}$ showed improvement in columella deviation, which represents an increase in columella length. A similar observation was reported by Wang et al. ${ }^{16}$ Another significant factor in achieving nasal symmetry and facial aesthetics is nostril width and nostril height on both the cleft and non-cleft sides. The nostril height on both sides increased significantly $(2.1 \mathrm{~mm}$ and $3.07 \mathrm{~mm}$, respectively) after extraoral NAM therapy in this study. A significant improvement in nose symmetry caused by an increase in nostril height was also observed by Monasterio et al. ${ }^{28}$ and Doruk and $\mathrm{Kiliç}^{37}$. In CLP deformity, the flattened alar cartilage on cleft side and deviated nasal tip toward the non-cleft side increase the nostril width on the cleft side and decrease it on the non-cleft side. Therefore, it is desirable to decrease the nostril width on the cleft side and increase it on non-cleft side. In this study, the nostril width decreased by $3.5 \mathrm{~mm}$ on the cleft side and increased by $1.73 \mathrm{~mm}$ on the non-cleft side. This observation is comparable to that reported by Monasterio et al. $^{28}$.

One of the goals of NAM therapy is to align and arrange the alveolar cleft segments by reducing the anterior alveolar cleft width. We found a significant reduction in the dimen- sions of the anterior alveolar cleft width, with a mean reduction of $4.8 \mathrm{~mm}$ using the extraoral NAM technique, which is similar to the observation of Monasterio et al. ${ }^{28}$, who reported a mean reduction of $5.3 \mathrm{~mm}$. Another factor contributing to the success of NAM therapy is the length of the larger and smaller segments. In a unilateral CLP patient, Koya et al. ${ }^{17}$ observed that extraoral NAM therapy had no effect on maxillary growth, as demonstrated by a significant increase in the length of both the larger and smaller segments. We also found a significant increase in the length of both segments after extraoral NAM therapy: by $3 \mathrm{~mm}$ for the larger segment and 2.5 $\mathrm{mm}$ for the smaller segment. In their case report about extraoral NAM, Wang et al. ${ }^{16}$ reported an increase of $3.9 \mathrm{~mm}$ for the larger segment and $4.1 \mathrm{~mm}$ for the smaller segment. Our results indicate that all the extraoral anthropometric parameters and intraoral CLP parameters improved significantly after extraoral NAM therapy.

The extraoral NAM technique is a promising approach that significantly reduces the complications and compliance issues associated with intraoral NAM. The concept of the extraoral approach was first described in 1993 by Larson et al. ${ }^{38}$, who developed an extraoral device for presurgical orthopedic procedures. It consisted of a T-shaped traction device that was supported by a rubber band and headcap. That device applied transverse pressure along the base of the nasal septum toward the cleft side to rotate the larger cleft segment $^{38}$. However, that appliance was bulky and its fabrication was time consuming. In 2005, Doruk and Kiliç ${ }^{37}$ developed an extraoral appliance that consisted of a nasal stent with a helical spring that extended from the forehead to the chin and was supported by a circumferential headband. An intraoral plate was inserted separately for alveolus molding. The limitation of that appliance was its complex design, which could obstruct feeding.

In 2013, Wang et al. ${ }^{16}$ designed an extraoral appliance that continuously applied low-grade pressure ${ }^{39}$. That appliance consisted of two parts: Steri-strips and a wire component that included a nasal stent. The Steri-strips applied transverse pressure along the base of the nasal septum toward the cleft side, which increased the length of the columella and approximate the cleft segments ${ }^{40}$. It also helped to eliminate the laterally displacing pulling force from the unstrained orbicularis oris, thereby helping in the rearrangement of the cleft segments $^{38}$. The wire component, along with the nasal stent, helped to mold the nasal cartilage more precisely. The advantage of this appliance is that it is compact, precise, requires less clinical time for appliance adjustment than in- 
traoral appliances, and reduces the number of visits required for activation. Therefore, in this study, we used the appliance designed by Wang et al. ${ }^{16}$ for presurgical NAM and compared its results with those from Liou's intraoral NAM approach ${ }^{12}$.

We found that the extraoral approach effectively changed the relevant nasal and alveolar parameters in ways similar to the changes seen with the intraoral NAM technique. In fact, the differences between the techniques was not statistically significant for any of the extraoral and intraoral parameters. Thus, the extraoral NAM technique is as effective as the intraoral NAM technique.

Our literature search revealed insufficient data comparing extraoral and intraoral NAM techniques. Monasterio et al. ${ }^{28}$ compared an extraoral nasal elevator with Grayson's intraoral NAM technique and found that the extraoral NAM technique effectively reduced the cleft deformity and improved nasal symmetry. They also found that both techniques were equally effective in treating the cleft deformity, which is in accordance with the findings of this study.

In this study, the intraoral and extraoral NAM techniques did not differ significantly in treatment effectiveness. However, the extraoral NAM technique exhibited a reduction in complications and better compliance and parental acceptance.

Because few studies have examined extraoral NAM techniques, our results cannot be compared extensively. Therefore, we suggest further research on extraoral NAM techniques.

Limitations: A small sample size and short follow-up period are the primary limitations of this study. Other parameters, such as arch width, arch length, posterior cleft width, and columellar angle, could have been compared between the two groups. Long-term studies on the extraoral NAM technique are needed.

\section{Conclusion}

Both groups achieved significant improvement in the extraoral and intraoral parameters measured, without any statistically significant differences between them. Thus, the extraoral NAM technique is as effective as the intraoral technique in achieving significant nasal and alveolar changes in complete unilateral CLP patients. Additionally, it reduces the number of hospital visits needed for activation and the stress associated with inserting and removing the intraoral NAM plate and thereby improves compliance.

Therefore, extraoral NAM techniques can be used effectively for NAM.

\section{ORCID}

Ritesh Kalaskar, https://orcid.org/0000-0001-7403-3364

Priyanka Bhaje, https://orcid.org/0000-0003-1464-5478

Priyanka Sharma, https://orcid.org/0000-0001-8169-3432

Shruti Balasubramanian, https://orcid.org/0000-0002-76663981

Nupur Ninawe, https://orcid.org/0000-0003-1403-4634

Rajesh Ijalkar, https://orcid.org/0000-0001-6307-1373

\section{Authors' Contributions}

P.B. done the data collection, review of literature and statistical analysis. R.K. and P.S. performed data analysis and manuscript preparation. S.B. and R.I. helped with review and references. N.N. helped in manuscript review and editing. All authors have read and approved the final version of the manuscript.

\section{Acknowledgements}

We wish to thank all the parents who consented and agreed for the publication of data.

\section{Ethics Approval and Consent to Participate}

The study was approved by the Ethics Committee of Government Dental College Nagpur (GDCH N/SS/Ethic 2017/5866/2017.dt 17/10/17).

\section{Consent for Publishing Photographs}

Written informed consent was obtained from the patients for publication of this article and accompanying images.

\section{Conflict of Interest}

No potential conflict of interest relevant to this article was reported.

\section{References}

1. Grayson BH, Garfinkle JS. Early cleft management: the case for nasoalveolar molding. Am J Orthod Dentofacial Orthop 2014;145:134-42. https://doi.org/10.1016/j.ajodo.2013.11.011

2. Mossey PA, Shaw WC, Munger RG, Murray JC, Murthy J, Little J. Global oral health inequalities: challenges in the prevention and management of orofacial clefts and potential solutions. Adv Dent 
Res 2011;23:247-58. https://doi.org/10.1177/0022034511402083

3. Mossey PA, Little J, Munger RG, Dixon MJ, Shaw WC. Cleft lip and palate. Lancet 2009;374:1773-85. https://doi.org/10.1016/ S0140-6736(09)60695-4

4. Dixon MJ, Marazita ML, Beaty TH, Murray JC. Cleft lip and palate: understanding genetic and environmental influences. Nat Rev Genet 2011;12:167-78. https://doi.org/10.1038/nrg2933

5. Mossey PA, Little J. Epidemiology of oral clefts: an international perspective. In: Wyskynski DF, ed. Cleft lip and palate: from origin to treatment. Oxford: Oxford University Press; 2002:127-58.

6. Berkowitz S. Cleft lip and palate: diagnosis and management. 3rd ed. Berlin: Springer; 2013.

7. Wong FW, King NM. The oral health of children with clefts-a review. Cleft Palate Craniofac J 1998;35:248-54. https://doi. org/10.1597/1545-1569_1998_035_0248_tohocw_2.3.co_2

8. Hunt $\mathrm{O}$, Burden D, Hepper $\overline{\mathrm{P}}$, Johnston $\mathrm{C}$. The psychosocial effects of cleft lip and palate: a systematic review. Eur J Orthod 2005;27:274-85. https://doi.org/10.1093/ejo/cji004

9. Pfeifer TM, Grayson BH, Cutting CB. Nasoalveolar molding and gingivoperiosteoplasty versus alveolar bone graft: an outcome analysis of costs in the treatment of unilateral cleft alveolus. Cleft Palate Craniofac J 2002;39:26-9. https://doi.org/10.1597/15451569_2002_039_0026_nmagva_2.0.co_2

10. Grayson BH, Santiago PE, Brecht LE, Cutting CB. Presurgical nasoalveolar molding in infants with cleft lip and palate. Cleft Palate Craniofac J 1999;36:486-98. https://doi.org/10.1597/1545156919990360486 pnmiiw 2.3.co 2

11. Figueroa AA, Polley JW. Orthodontics in cleft lip and palate management. In: Mathes SJ, ed. Plastic surgery: pediatric plastic surgery. 2nd ed. Philadelphia: Saunders; 2006:271-310.

12. Liou EJ, Subramanian M, Chen PK, Huang CS. The progressive changes of nasal symmetry and growth after nasoalveolar molding: a three-year follow-up study. Plast Reconstr Surg 2004;114:858-64. https://doi.org/10.1097/01.prs.0000133027.04252.7a

13. Matsuo K, Hirose T, Tomono T, Iwasawa M, Katohda S, Takahashi $\mathrm{N}$, et al. Nonsurgical correction of congenital auricular deformities in the early neonate: a preliminary report. Plast Reconstr Surg 1984;73:38-51. https://doi.org/10.1097/00006534-19840100000009

14. Liao YF, Hsieh YJ, Chen IJ, Ko WC, Chen PK. Comparative outcomes of two nasoalveolar molding techniques for unilateral cleft nose deformity. Plast Reconstr Surg 2012;130:1289-95. https://doi. org/10.1097/PRS.0b013e31826d16f3

15. Sischo L, Clouston SA, Phillips C, Broder HL. Caregiver responses to early cleft palate care: a mixed method approach. Health Psychol 2016;35:474-82. https://doi.org/10.1037/hea0000262

16. Wang Q, Zhou L, Zhao JZ, Ko EW. An extraoral nasoalveolar molding technique in complete unilateral cleft lip and palate. Plast Reconstr Surg Glob Open 2013;1:e26. https://doi.org/10.1097/ GOX.0b013e31829e0d4b

17. Koya S, Husain A, Khader M. Complete bilateral cleft lip and palate with protruding premaxilla: a multidisciplinary approach. Arch Med Health Sci 2018;6:298-9. https://doi.org/10.4103/amhs. amhs $136 \_18$

18. Murthy PS, Deshmukh S, Bhagyalakshmi A, Srilatha K. Pre surgical nasoalveolar molding: changing paradigms in early cleft lip and palate rehabilitation. J Int Oral Health 2013;5:70-80.

19. Yang S, Stelnicki EJ, Lee MN. Use of nasoalveolar molding appliance to direct growth in newborn patient with complete unilateral cleft lip and palate. Pediatr Dent 2003;25:253-6.

20. Grayson BH, Maull D. Nasoalveolar molding for infants born with clefts of the lip, alveolus, and palate. Semin Plast Surg 2005;19:294-301. https://doi.org/10.1055/s-2005-925902

21. McNeil CK. Orthodontic procedures in the treatment of congenital cleft palate. Dent Rec (London) 1950;70:126-32.

22. Dogliotti PL, Bennún RD, Losoviz EA, Ganiewich E. [Non-surgical treatment of nasal deformity in the cleft patient]. Rev. Ateneo Ar- gent Odontol 1991;27:31-5. Spanish.

23. Chen YF, Liao YF. A modified nasoalveolar molding technique for correction of unilateral cleft nose deformity. J Craniomaxillofac Surg 2015;43:2100-5. https://doi.org/10.1016/j.jcms.2015.10.003

24. Shetty V, Vyas HJ, Sharma SM, Sailer HF. A comparison of results using nasoalveolar moulding in cleft infants treated within 1 month of life versus those treated after this period: development of a new protocol. Int J Oral Maxillofac Surg 2012;41:28-36. https://doi. org/10.1016/j.ijom.2011.09.002

25. Shapira Y, Lubit E, Kuftinec MM, Borell G. The distribution of clefts of the primary and secondary palates by sex, type, and location. Angle Orthod 1999;69:523-8. https://doi.org/10.1043/00033219(1999)069<0523:TDOCOT $>2.3 . C O ; 2$

26. Tabaie S. Stopping female feticide in India: the failure and unintended consequence of ultrasound restriction. J Glob Health 2017:7:010304. https://doi.org/10.7189/jogh.07.010304

27. Jurkiewicz MJ, Bryant DL. Cleft lip and palate in dogs: a progress report. Cleft Palate J 1968;5:30-6.

28. Monasterio L, Ford A, Gutiérrez C, Tastets ME, García J. Comparative study of nasoalveolar molding methods: nasal elevator plus DynaCleft ${ }^{\circledR}$ versus NAM-Grayson in patients with complete unilateral cleft lip and palate. Cleft Palate Craniofac J 2013;50:54854. https://doi.org/10.1597/11-245

29. Zuhaib M, Bonanthaya K, Parmar R, Shetty PN, Sharma P. Presurgical nasoalveolar moulding in unilateral cleft lip and palate. Indian J Plast Surg 2016;49:42-52. https://doi.org/10.4103/09700358.182235

30. Gomez DF, Donohue ST, Figueroa AA, Polley JW. Nasal changes after presurgical nasoalveolar molding (PNAM) in the unilateral cleft lip nose. Cleft Palate Craniofac J 2012;49:689-700. https:// doi.org/10.1597/11-007

31. Pai BC, Ko EW, Huang CS, Liou EJ. Symmetry of the nose after presurgical nasoalveolar molding in infants with unilateral cleft lip and palate: a preliminary study. Cleft Palate Craniofac J 2005;42:658-63. https://doi.org/10.1597/04-126.1

32. Singh GD, Levy-Bercowski D, Santiago PE. Three-dimensional nasal changes following nasoalveolar molding in patients with unilateral cleft lip and palate: geometric morphometrics. Cleft Palate Craniofac J 2005;42:403-9. https://doi.org/10.1597/04-063.1

33. Patel D, Goyal R. Pre-surgical nasoalveolar moulding in patient with unilateral cleft of lip, alveolus and palate: case report. J Plast Reconstr Aesthet Surg 2012;65:122-6. https://doi.org/10.1016/ j.bjps.2011.06.011

34. Prahl C, Kuijpers-Jagtman AM, van't Hof MA, Prahl-Andersen B. A randomised prospective clinical trial into the effect of infant orthopaedics on maxillary arch dimensions in unilateral cleft lip and palate (Dutchcleft). Eur J Oral Sci 2001;109:297-305. https://doi. org/10.1034/j.1600-0722.2001.00056.x

35. Mishima K, Mori Y, Sugahara T, Minami K, Sakuda M. Comparison between palatal configurations in UCLP infants with and without a Hotz plate until four years of age. Cleft Palate Craniofac J 2000;37:185-90. https://doi.org/10.1597/15451569_2000_037_0185_cbpciu_2.3.co_2

36. Sabarinath VP, Thombare $\mathrm{P}$, Hazarey PV, Radhakrishnan V, Agrekar S. Changes in maxillary alveolar morphology with nasoalveolar molding. J Clin Pediatr Dent 2010;35:207-12. https://doi. org/10.17796/jcpd.35.2.f80u21362566qr34

37. Doruk C, Kiliç B. Extraoral nasal molding in a newborn with unilateral cleft lip and palate: a case report. Cleft Palate Craniofac J 2005;42:699-702. https://doi.org/10.1597/04-134r.1

38. Larson M, Sällström KO, Larson O, McWilliam J, Ideberg M. Morphologic effect of preoperative maxillofacial orthopedics (T-traction) on the maxilla in unilateral cleft lip and palate patients. Cleft Palate Craniofac J 1993;30:29-34. https://doi.org/10.1597/154515691993 030_0029 meopmo_2.3.co_2

39. Da Silveira AC, Oliveira N, Gonzalez S, Shahani M, Reisberg D, Daw Jr JL, et al. Modified nasal alveolar molding appliance for 
management of cleft lip defect. J Craniofac Surg 2003;14:700-3. https://doi.org/10.1097/00001665-200309000-00018

40. Nordin KE, Larson O, Nylén B, Eklund G. Early bone grafting in complete cleft lip and palate cases following maxillofacial orthopedics. I. The method and the skeletal development from seven to thirteen years of age. Scand J Plast Reconstr Surg 1983;17:33-50. https://doi.org/10.3109/02844318309007177
How to cite this article: Kalaskar R, Bhaje P, Sharma P, Balasubramanian S, Ninawe N, Ijalkar R. Comparative evaluation of nasal and alveolar changes in complete unilateral cleft lip and palate patients using intraoral and extraoral nasoalveolar molding techniques: randomized controlled trial. J Korean Assoc Oral Maxillofac Surg 2021;47:257-268. https://doi.org/10.5125/jkaoms.2021.47.4.257 